\title{
THE PARENT COMPANY PUZZLE ON THE GERMAN STOCK MARKET
}

Dipl.-Kfm. Martin Eling (martin.eling@unisg.ch),

University of St. Gallen, Institute of Insurance Economics,

Kirchlistrasse 2, 9000 St. Gallen, Switzerland,

Tel.: +41-71-2434093, Fax: +41-71-2434040

Prof. Dr. Frank Schuhmacher (schuhmacher@wifa.uni-leipzig.de),

University of Leipzig, Department of Finance, Postfach 100920,

04009 Leipzig, Germany,

Tel.: +49-341-9733670, fax: +49-341-9733679

We would like to thank the referees for several helpful comments.

\section{Introduction}

On December 03, 1999, Mobilcom offered 23\% (4 million shares) of its subsidiary Freenet through an initial public offering (IPO). On the first trading day, the market value of Mobilcom was $€ 3$, 138.84 million, while its ownership stake in Freenet was worth $€ 1,334.03$ million. In subsequent years this relationship changed. On September 13, 2002, the market value of Mobilcom's ownership stake in Freenet first exceeded the market value of the Mobilcom stocks. After high price losses, the Mobilcom stocks were worth only $€ 70.95$ million, while Mobilcom's ownership stake in Freenet was worth $€ 73.65$ million. This development climaxed on August 25, 2003, when the market value of Mobilcom's Freenet stake exceeded Mobilcom's stock market value by about $31 \%$. At that time, numerous buy recommendations regarding Mobilcom were published.[1] Since then the relationship between the market values of the Mobilcom stocks and Mobilcom's stake has changed again. On September 03, 2003, the market value of Mobilcom shares exceeded the market value of its stake in Freenet. On December 30, 2003, Mobilcom was worth $€ 839.67$ million and the ownership stake was valued at $€ 551.75$ million. Situations where a firm's market value is less than the value of its ownership stake in a publicly traded subsidiary are commonly referred to as "negative stub values"[2] or "parent company puzzles"[3]. According to MITCHELL/PULVINO/ STAFFORD (2002), p. 552, these situations suggest clear arbitrage opportunities. Using data from 1985 through 2000, MITCHELL/PULVINO/ STAFFORD (2002) constructed a sample of 82 negative stub values for analysing the impediments to arbitraging relative mispricings of corporate cross holdings. They concluded that a main factor that prevents arbitrageurs from quickly exploiting the mispricings and forcing prices to fundamental values is the costs associated with imperfect information. There is uncertainty about both the number of negative stub value situations which might be exploited and the magnitude of these opportunities. Furthermore, there is uncertainty about the distribution of returns of investment strategies based on negative stub values. In addition, it might be difficult to say whether a negative stub value is caused by a mispricing or by fairly priced firms with, for example, major off-balance sheet liabilities as a rational explanation for the negative stub value. When the ex ante benefits from identifying and exploiting negative stub values are uncertain and the fixed costs of 
becoming informed are sufficiently large, arbitrageurs may not enter this business and quickly force prices to fundamental values.

To shed some light on these uncertainty issues, we have collected five years of German stock market data from 1999 to 2003 and carefully analysed their characteristics, much as MITCHELL/PULVINO/ STAFFORD (2002) have done. In the first step, we constructed a sample of eleven cases where a firm's market value is less than the value of its ownership stake in a publicly traded subsidiary.[4] In the second step, we analysed the performance of investment strategies based on negative stub values. We considered two negative stub value investment strategies: a "parent long" and a "subsidiary long" investment strategy. In order to implement the investment strategies, we constructed buy and sell signals based on a value ratio which is defined as the ratio between the market value of the stake of the subsidiary's equity held by the parent and the market value of the parent's equity. For each parent/subsidiary pair and for each point in time, we calculated the value ratio and started an investment when the value ratio exceeded a buy threshold. Normally, the investment was terminated when the value ratio fell below a sell threshold. We found that, on average, the "parent long" investment strategy produced a return of more than $20 \%$ in excess of the return of a market index and the "subsidiary long" investment strategy produced an insignificantly negative excess return of $1.32 \%$. Hence, on average, only the stock price of the parent company converged, while the stock price of the subsidiary changed with the market. This is an interesting result because it supports the view that the parent stocks are underpriced, and it does not support the view that the subsidiaries are overpriced because of short selling constraints.

Despite these positive results, negative stub value investments are not risk-free investments. In at least $25 \%$ of the cases in which the value ratio exceeded the buy threshold, it did not fall below the sell threshold either within one year after the initial investment date or as of December 30, 2003. In both cases, the investments were terminated, although the prices did not converge Tas expected or desired. There are two explanations for these "bad outcomes": First, the parent/subsidiary pair is mispriced and mispricing corrections take longer than expected. Second, the firms are fairly priced and there is a rational explanation for the negative stub value.

In the literature, there are several potential explanations for the parent company puzzle. For example, CORNELL/LIU (2001) examined seven instances of the parent company puzzle and tried to explain these cases in terms of traditional closed-end fund discount theories, which are taxes, agency costs, liquidity effects, and noise trader risk.[5] CORNELL/LIU (2001), p. 365, concluded that these theories are not able to explain their parent-company-puzzle examples. According to CORNELL/LIU (2001), the only explanation consistent with all the results is that the subsidiary is overpriced because of short selling constraints. This supports the explanation offered by many practitioners. Short selling constraints and high demand can produce irrationally high prices. SCHILL/ZHOU (2001) and LAMONT/THALER (2003) report similar findings.[6]

The remainder of the paper is organised as follows. Section 2 describes the data collected. In Section 3, we define and implement negative stub value investment strategies and report the returns and risks of these investment strategies. In Section 4, we apply traditional closed-end fund discount and other theories to our sample of negative stub values. Section 5 contains the conclusion.

\section{Determination of Negative Stub Values}

\subsection{Approach: Identification of Negative Stub Values}

The stub value is defined as the market value (MV) of the parent's equity less the market value 
of its ownership stake in a publicly traded subsidiary less the market value of net other assets (see formula (1)). The market value of net other assets is defined as the market value of the parent's non-subsidiary (other) assets less the parent's unconsolidated liabilities.

$$
\begin{gathered}
\text { Stub Value }=M V_{\text {Parent Equity }}-M V_{\text {Parent Stake }} \\
-\underbrace{\left(M V_{\text {Parent Other Assets }}-M V_{\text {Parent Liabilities }}\right)}_{M V_{\text {Net Other Assets }}}
\end{gathered}
$$

When a stub value is negative, the parent/ subsidiary pair is included in our sample of parent company puzzles. To determine whether the stub value is negative, we use two different methods. The first method assumes that the market value of the parent's other assets is equal to the market value of the parent's debt. Of course, this assumption is problematic, but it is a first approximation and it allows us to compare our results to MITCHELL/PULVINO/STAFFORD (2002), who use the same assumption.[7] The second method assumes that the market value of the parent's net other assets can be calculated on the basis of book values taken from balance sheets. This assumption is problematic again because book values may not exactly describe market values. For example, off-balance sheet liabilities are completely ignored. Nevertheless, the second method may be a better approximation than the first one and might explain a significant portion of the stub value.

To construct a sample of negative stub value situations, we use a two-stage selection process: In the first stage, a preselection is carried out using various databases in the internet (OnVista, http://www.onvista.de, GoingPublic, http://www. goingpublic-online.de, and Cortal Consors, http:// www.cortalconsors.de). In the second stage, the sample is reviewed in detail using annual and interim reports as well as stock data from YahooFinance (http://de.finance.yahoo.com).
In the first stage, companies are selected in two different ways. It is known from other studies of the parent company puzzle that negative stub values often arise following equity carve-outs. Therefore, the analysis of all German IPOs between January 1999 and December 2003 is a good starting point for determining negative stub values. Using databases of OnVista and GoingPublic, we identify 26 carve-outs from 365 IPOs. These 26 cases are examined in detail in the second stage. To find further cases, a second preselection is carried out, which uses data on market capitalisation and ownership stakes of German corporations from Cortal Consors. On September 05, 2003, 302 corporations are listed in the DAX 100, the SDAX, and the (former) Nemax All Share. For a negative stub value to come into question, a company needs to hold an ownership stake in an exchange traded company. For the 302 corporations, this is the case in 48 instances. Furthermore, the market value of the parent's stake must be significant relative to the parent's equity market value. To be selected in the first stage, the market value of the stake must at least be $33.33 \%$ of the parent's equity market value. Altogether 18 companies satisfy this condition. Of these, five enterprises are already part of the carve-out sample. Thus a sample of 39 parent/subsidiary pairs is the result of the firststage of the selection process.

In the second stage, all 39 potential negative stub values are reviewed in detail. For this purpose, the market capitalisation of the parent and the subsidiary as well as the market value of the parent company's stake in the subsidiary are calculated for each day between January 4, 1999, and December 30, 2003. With this choice of time period, all possible capital market conditions are investigated: a sharp rise in the market (until March 2000), the following slump (until March 2003), and finally the phase of recovering markets (until December 2003). The data concerning the number of shares outstanding and the number of subsidiary shares held by the parent are obtained 
from annual and interim reports. The share prices are taken from Yahoo Finance. Using the collected data, we calculate the stub value under the assumption that the market value of net other assets is zero (our first method). Twelve of the 39 parent/subsidiary pairs show a negative stub value in the examination period.

Finally, we consider the remaining twelve cases in order to see whether their negative stub values might be explained by net other assets. Using annual and interim reports, the market values of net other assets are estimated on the basis of book values (our second method). In one case (Babcock Borsig and Schumag), the investigation led to the exclusion of the parent/ subsidiary pair from the sample due to a high level of indebtedness. Therefore, eleven instances of the parent company puzzle remain for further examination.

\subsection{Results: Companies with Negative Stub Values}

The sample consists of eleven parent/subsidiary pairs. Table 1 lists for each pair the name of the parent company and its subsidiary, the branches in which the parent and subsidiary operate, the percentage of shares held by the parent on December 30, 2003, and the background information on how the parent obtained its stake in the subsidiary.[8]

In contrast to existing studies of the parent company puzzle, which focus mainly on the technology industry,[12] we find a balanced mixture of companies belonging to the "Old Economy", e.g., engineering (Boewe Systec), and the "New Economy", e.g., IT-Software (USU Software). In the sample there are very large companies, e.g., Allianz (market capital-

Table 1: Sample of Parent/Subsidiary Pairs with Negative Stub Values

\begin{tabular}{|c|c|c|c|c|}
\hline Case & $\begin{array}{c}\text { Parent } \\
\text { (Branch) }\end{array}$ & $\begin{array}{l}\text { Subsidiary } \\
\text { (Branch) }\end{array}$ & $\begin{array}{l}\text { Percentage held by } \\
\text { Parent on } 30 / 12 / 03\end{array}$ & Background \\
\hline 1 & $\begin{array}{l}\text { Mobilcom AG } \\
\text { (Telecommunication) }\end{array}$ & $\begin{array}{l}\text { Freenet.de AG } \\
\text { (Internet-Services) }\end{array}$ & $52.89 \%$ & $\begin{array}{l}\text { Carve-out } \\
03 / 12 / 99\end{array}$ \\
\hline 2 & $\begin{array}{l}\text { Augusta Technologie AG } \\
\text { (IT-Services) }\end{array}$ & $\begin{array}{l}\text { Pandatel AG } \\
\text { (Network-Technology) }\end{array}$ & $57.90 \%$ & $\begin{array}{l}\text { Carve-out } \\
02 / 11 / 99\end{array}$ \\
\hline 3 & $\begin{array}{l}\text { Fresenius AG } \\
\text { (Medical Equipment) }\end{array}$ & $\begin{array}{l}\text { Fresenius Medical Care AG } \\
\text { (Medical Equipment) }\end{array}$ & $\begin{array}{c}50.80 \% \\
\text { (of the Ordinary Shares) }\end{array}$ & $\begin{array}{l}\text { Carve-out } \\
02 / 10 / 96\end{array}$ \\
\hline 4 & $\begin{array}{l}\text { Wanderer Werke AG } \\
\text { (Holdings) }\end{array}$ & $\begin{array}{l}\text { Boewe Systec AG } \\
\text { (Engineering) }\end{array}$ & $51.00 \%$ & $\begin{array}{l}\text { Carve-out } \\
03 / 04 / 92\end{array}$ \\
\hline 5 & $\begin{array}{l}\text { USU Software AG } \\
\text { (IT-Software) }\end{array}$ & $\begin{array}{l}\text { USU AG } \\
\text { (Special Software) }\end{array}$ & $95.99 \%$ & $\begin{array}{l}\text { Acquisition } \\
11 / 03 / 02\end{array}$ \\
\hline 6 & $\begin{array}{l}\text { Media [Netcom] AG } \\
\text { (Entertainment) }\end{array}$ & $\begin{array}{l}\text { Internolix AG } \\
\text { (Special Software) }\end{array}$ & $95.10 \%$ & $\begin{array}{l}\text { Acquisition } \\
04 / 07 / 01\end{array}$ \\
\hline 7 & $\begin{array}{l}\text { TAG Tegernsee AG } \\
\text { (Real Estate) }\end{array}$ & $\begin{array}{l}\text { Bau-Verein zu Hamburg AG } \\
\text { (Real Estate) }\end{array}$ & $87.92 \%$ & $\begin{array}{l}\text { Acquisition } \\
\text { 25/04/01 }\end{array}$ \\
\hline 8 & $\begin{array}{l}\text { Essential Wagniskapital KGaA } \\
\text { (Financial Services) }\end{array}$ & $\begin{array}{l}\text { November AG } \\
\text { (Biotechnology) }\end{array}$ & $10.56 \%$ & $\begin{array}{l}\text { Acquisition } \\
31 / 12 / 99\end{array}$ \\
\hline 9 & $\begin{array}{l}\text { Allianz AG } \\
\text { (Insurance) }\end{array}$ & $\begin{array}{l}18 \text { Subsidiaries [9] } \\
\text { (Diverse) }\end{array}$ & $20.49 \%$ * & $\begin{array}{l}\text { Acquisition of } \\
\text { many stakes }\end{array}$ \\
\hline 10 & $\begin{array}{l}\text { Münchener Rück AG } \\
\text { (Insurance) }\end{array}$ & $\begin{array}{l}6 \text { Subsidiaries [10] } \\
\text { (Diverse) }\end{array}$ & $24.74 \%$ * & $\begin{array}{l}\text { Acquisition of } \\
\text { many stakes }\end{array}$ \\
\hline 11 & $\begin{array}{l}\text { WCM AG } \\
\text { (Real Estate) }\end{array}$ & $\begin{array}{l}4 \text { Subsidiaries [11] } \\
\text { (Diverse) }\end{array}$ & $58.90 \%$ * & $\begin{array}{l}\text { Acquisition of } \\
\text { many stakes }\end{array}$ \\
\hline
\end{tabular}

*: Average of all stakes. 
isation $€ 38,413.69$ million on December 30, 2003), as well as very small companies, e.g., Augusta (market capitalisation $€ 33.60$ million on December 30, 2003). In addition, all market segments are contained in the sample, i.e., the prime standard (e.g., Münchener Rück) and the general standard (e.g., Bau-Verein zu Hamburg). In most cases (1 to 7 and 11), the percentage held by the parent is very high. In cases 9, 10 and 11, a large number of partially smaller stakes lead to a negative stub value. For example, for Allianz (case 9), we find 18 subsidiaries, but the average stake is only about $20.49 \%$. Four of the eleven instances are equity carve-outs. Moreover, in seven cases, the negative stub value was created after acquiring a stake in one or several subsidiaries.
Table 2 shows for each parent/subsidiary pair the time period and duration (in trading days) of the negative stub value situation as well as the maximum and minimum value ratios between January 4, 1999, and December 30, 2003. In the following, this time period is called the sample period or examination period.

The average duration of a negative stub value situation is 244.91 trading days. Of course, this time period with a negative stub value varies from case to case. In some cases, the negative stub value disappears after only one trading day (e.g., cases 3 and 5) while in other instances it lasts for the entire examination period (e.g., case 4). In addition, in many cases, a longer time period of negative stub values is at least temporarily inter-

\section{Table 2: Negative Stub Values}

\begin{tabular}{|c|c|c|c|c|c|}
\hline \multirow[b]{2}{*}{ Case } & \multirow{2}{*}{$\begin{array}{l}\text { Parent/ } \\
\text { Subsidiary }\end{array}$} & \multirow[b]{2}{*}{ Negative Stub Value Time Period } & \multirow[b]{2}{*}{ Duration } & \multicolumn{2}{|c|}{ Value Ratio } \\
\hline & & & & Minimum & Maximum \\
\hline 1 & $\begin{array}{l}\text { Mobilcom/ } \\
\text { Freenet }\end{array}$ & $\begin{array}{l}13 / 09 / 02,03 / 04 / 03,11 / 04 / 03 \text { to } 14 / 04 / 03, \\
30 / 06 / 03 \text { to } 02 / 09 / 03^{*}, 11 / 09 / 03\end{array}$ & 46 & 0.06 & 1.31 \\
\hline 2 & $\begin{array}{l}\text { Augusta Technologie/ } \\
\text { Pandatel }\end{array}$ & $\begin{array}{l}09 / 12 / 99 \text { to } 03 / 11 / 00,04 / 12 / 00 \text { to } 29 / 12 / 00 \\
08 / 10 / 02,14 / 01 / 03,27 / 01 / 03 \text { to } 07 / 02 / 03^{\star} \\
20 / 02 / 03 \text { to } 14 / 03 / 03,24 / 03 / 03 \text { to } 08 / 04 / 03^{*} \\
22 / 04 / 03 \text { to } 24 / 04 / 03,17 / 06 / 03\end{array}$ & 287 & 0.37 & 1.82 \\
\hline 3 & $\begin{array}{l}\text { Fresenius/ } \\
\text { Fresenius Medical Care }\end{array}$ & $27 / 03 / 03$ & 1 & 0.61 & 1.00 \\
\hline 4 & $\begin{array}{l}\text { Wanderer Werke/ } \\
\text { Boewe Systec }\end{array}$ & $04 / 01 / 99$ to $30 / 12 / 03$ & 1263 & 1.39 & 2.49 \\
\hline 5 & $\begin{array}{l}\text { USU Software/ } \\
\text { USU }\end{array}$ & 01/10/03 & 1 & 0.36 & 1.06 \\
\hline 6 & $\begin{array}{l}\text { Media }[\text { Netcom]/ } \\
\text { Internolix }\end{array}$ & $26 / 11 / 03$ to $09 / 12 / 03^{*}$ & 8 & 0.18 & 1.12 \\
\hline 7 & $\begin{array}{l}\text { TAG Tegernsee/ } \\
\text { Bau-Verein zu Hamburg }\end{array}$ & $\begin{array}{l}20 / 12 / 02 \text { to } 27 / 12 / 02,24 / 01 / 03 \text { to } 14 / 03 / 03^{*} \\
12 / 05 / 03 \text { to } 05 / 06 / 03^{*}, 14 / 11 / 03 \text { to } 30 / 12 / 03\end{array}$ & 85 & 0.24 & 1.41 \\
\hline 8 & $\begin{array}{l}\text { Essential Wagniskapital/ } \\
\text { November }\end{array}$ & $\begin{array}{l}17 / 04 / 02 \text { to } 18 / 04 / 02,03 / 06 / 02 \text { to } 20 / 06 / 02^{*} \\
28 / 06 / 02 \text { to } 06 / 01 / 03^{*}, 19 / 05 / 03 \text { to } 30 / 12 / 03^{*}\end{array}$ & 290 & 0.21 & 3.20 \\
\hline 9 & $\begin{array}{l}\text { Allianz/ } \\
\text { Diverse }\end{array}$ & $01 / 08 / 02$ to $09 / 06 / 03,30 / 06 / 03$ to $01 / 07 / 03$ & 217 & 0.64 & 1.80 \\
\hline 10 & $\begin{array}{l}\text { Münchener Rück/ } \\
\text { Diverse }\end{array}$ & $\begin{array}{l}19 / 09 / 02 \text { to } 09 / 10 / 02^{*}, 12 / 03 / 03,27 / 03 / 03 \text { to } \\
16 / 04 / 03^{*}, 20 / 05 / 03 \text { to } 26 / 05 / 03^{*}, 09 / 06 / 03 \\
16 / 06 / 03 \text { to } 18 / 08 / 03^{*}, 28 / 08 / 03 \text { to } 29 / 09 / 03^{*}\end{array}$ & 94 & 0.63 & 1.20 \\
\hline 11 & $\begin{array}{l}\text { WCM/ } \\
\text { Diverse }\end{array}$ & $15 / 05 / 02$ to $31 / 05 / 02^{\star}, 17 / 06 / 02$ to $30 / 12 / 03$ & 402 & 0.54 & 6.16 \\
\hline Average & & & 244.91 & 0.48 & 2.05 \\
\hline
\end{tabular}

*: With brief interruptions (up to three trading days). 
Table 3: Buy and Sell Signals

\begin{tabular}{lcc}
\hline Threshold & Buy Signal & Sell Signal \\
\hline Standard & Value Ratio $>1.00$ & Value Ratio $<0.80$ \\
Moderate & Value Ratio $>1.25$ & Value Ratio $<1.00$ \\
Cautious & Value Ratio $>1.50$ & Value Ratio $<1.00$ \\
\hline
\end{tabular}

rupted. The value ratio is also subject to large fluctuations. While the average minimum value ratio is 0.48 , the average maximum ratio is 2.05 .

\section{Negative Stub Value Investments}

In this section, the performance of investment strategies based on parent company puzzle situations is analysed. Such strategies may represent interesting investment opportunities, e.g., for hedge funds that pursue event-driven strategies.[13] Within these investments, we analyse whether a speculation on changes in the pricing relationship between parent and subsidiary may be an attractive investment. Therefore we need to start and terminate investments following certain criteria.

\subsection{Implementing the Investment Strategy}

To implement an investment strategy based on negative stub values, we first define threshold values which signal buy and sell decisions when the value ratio of a particular parent/subsidiary pair exceeds or falls below a threshold. In order to be able to compare our results, we follow MITCHELL/PULVINO/STAFFORD (2002) once again and use three different buy and sell thresholds, which are given in the following table (Table 3). In the standard case, an investment is started when the value ratio exceeds 1.00 , and the investment is terminated when the value ratio falls below 0.80.[14] A buy threshold of 1.00 implies that the investor believes that the stock prices are relatively mispriced because the market value of the parent's ownership stake in the subsidiary is higher than the market value of the parent shares. The moderate and cautious thresholds give the investors some cushion over their estimates of mispricing.[15]

Second, we consider two possible investment strategies, a "parent long" and a "subsidiary long" investment strategy. Table 4 shows the investment strategies and the calculation of excess returns for both investment strategies.

The investment strategies are based on the expectation that, with the appearance of a negative stub value, the parent's and the subsidiary's stock prices are relatively mispriced and that the stock prices converge in a way which eliminates the mispricing. Therefore, a long position in the parent in combination with a short position in the subsidiary might be a promising investment strategy. However, since many market participants do not have the possibility of short selling and, in some cases, short sales may not be at all possible, we consider a long position in the parent and compare this to a long position in the subsidiary. Following the "parent long" investment strategy, shares of the parent company are bought or sold based on buy signals or sell signals, respectively. Similarly, the "subsidiary long" investment strat-

Table 4: Investment Strategies

\begin{tabular}{lcc}
\hline \multicolumn{1}{c}{ Strategy } & Arrangement & Calculation of Excess Return \\
\hline Parent Long & Buy the Parent & $\mathrm{ER}_{\mathrm{P}}=\mathrm{R}_{\mathrm{P}}-\mathrm{R}_{\mathrm{CDAX}}=\frac{\text { Price }_{\mathrm{P}_{\mathrm{EX}}}}{\text { Price }_{\mathrm{P}_{\mathrm{EN}}}}-\frac{\text { Price }_{\mathrm{CDAX}}}{\text { Price }_{\mathrm{CDAX}}}$ \\
Subsidiary Long & Buy the Subsidiary & $\mathrm{ER}_{\mathrm{S}}=\mathrm{R}_{\mathrm{S}}-\mathrm{R}_{\mathrm{CDAX}}=\frac{\text { Price }_{\mathrm{SXX}_{\mathrm{EX}}}}{\text { Price }_{\mathrm{S}_{\mathrm{EN}}}}-\frac{\text { Price }_{\mathrm{CDAX}}}{\text { Price }_{\mathrm{CDAX}}}$ \\
\hline
\end{tabular}


egy requires buy and sell decisions regarding the subsidiary's stock. From the results of these two strategies, conclusions about the success of a longshort strategy can be drawn.

In order to correct the returns for market influences, excess returns of the parent $\left(E R_{P}\right)$ and the subsidiary $\left(\mathrm{ER}_{\mathrm{S}}\right)$ are calculated. The excess return is computed as the difference between the return of the parent $\left(\mathrm{R}_{\mathrm{P}}\right)$ or the subsidiary $\left(\mathrm{R}_{\mathrm{S}}\right)$ and the return of the Composite DAX Performance Index $\left(\mathrm{R}_{\mathrm{CDAX}}\right)$.[16] EN and EX denote the dates when the stocks are bought (entry) and sold (exit). The CDAX consists of all German companies listed in the prime and general standard. It measures the development of the entire German stock market and therefore seems to be suitable for analysis purposes.

The maximum investment period is one year. This means that an investment is terminated either when we receive a sell signal or 250 trading days after initialisation. The investments which are not sold until December 30, 2003, are automatically liquidated at this date. Transaction costs are not considered.[17] In cases with several subsidiaries (e.g., Allianz with 18 subsidiaries) or several stock categories (e.g., Fresenius ordinary and preference shares), an equal weighted investment is made in the respective subsidiaries or stock categories. Returns are calculated using the adjusted closing prices offered by Yahoo Finance (corrected for dividends and splits). Using a parametric t-test and a non-parametric sign rank test according to Wilcoxon, the excess returns of all investments are tested for statistical significance.[18]

\subsection{Performance of Negative Stub Value Investments}

At first, the performance of the two investment strategies is analysed for the standard thresholds. The results for the standard thresholds are subsequently consolidated and compared with the other buy and sell thresholds. Table 5 describes the investment decisions for the standard case. In the first column, all investments are numbered. The second column (together with Table 2) describes the company which is bought and sold in each investment. The third and fourth columns show the dates at which the investments are started and terminated. The fifth column gives the holding period, which is defined as the number of trading days between the buy and sell decision. The sixth column shows the maximum value ratio during the holding period. In order to calculate the excess return of each investment, the return of an investment in the CDAX is given in the seventh column. Finally, the last four columns show both the non-adjusted returns and the excess returns for each investment. In addition, we calculate the results of the t-test and the sign rank test.

On the basis of the standard thresholds, 24 investments are started. For 18 of these 24 investments, the mispricing is eliminated within 250 trading days after the initial investment date. That corresponds to a convergence ratio of $75 \%$. The remaining six positions are liquidated automatically: three of them because the maximum investment period of one year is reached, the other three because the end of the sample period (30/ $12 / 03$ ) is reached. The average holding period (including the unsuccessful investments) is 81.75 trading days. A high holding period variation from 1 to 250 trading days can be observed. All "parent long" investments which are regularly terminated produce high excess returns. But in the case of a compulsory liquidation, these investments are less successful. A positive excess return can be earned only in one of six cases.

An average excess return of $25.97 \%$ is produced by a long position in the parent's shares.[19] This is significant for both test statistics. In contrast, the long positions in the subsidiary's shares show, on average, an insignificantly negative excess return of $1.32 \%$. As expected or desired, the "parent long" strategy produces a positive excess return, and the "subsidiary long" strategy a negative excess return. Obviously, a price adjustment takes place 


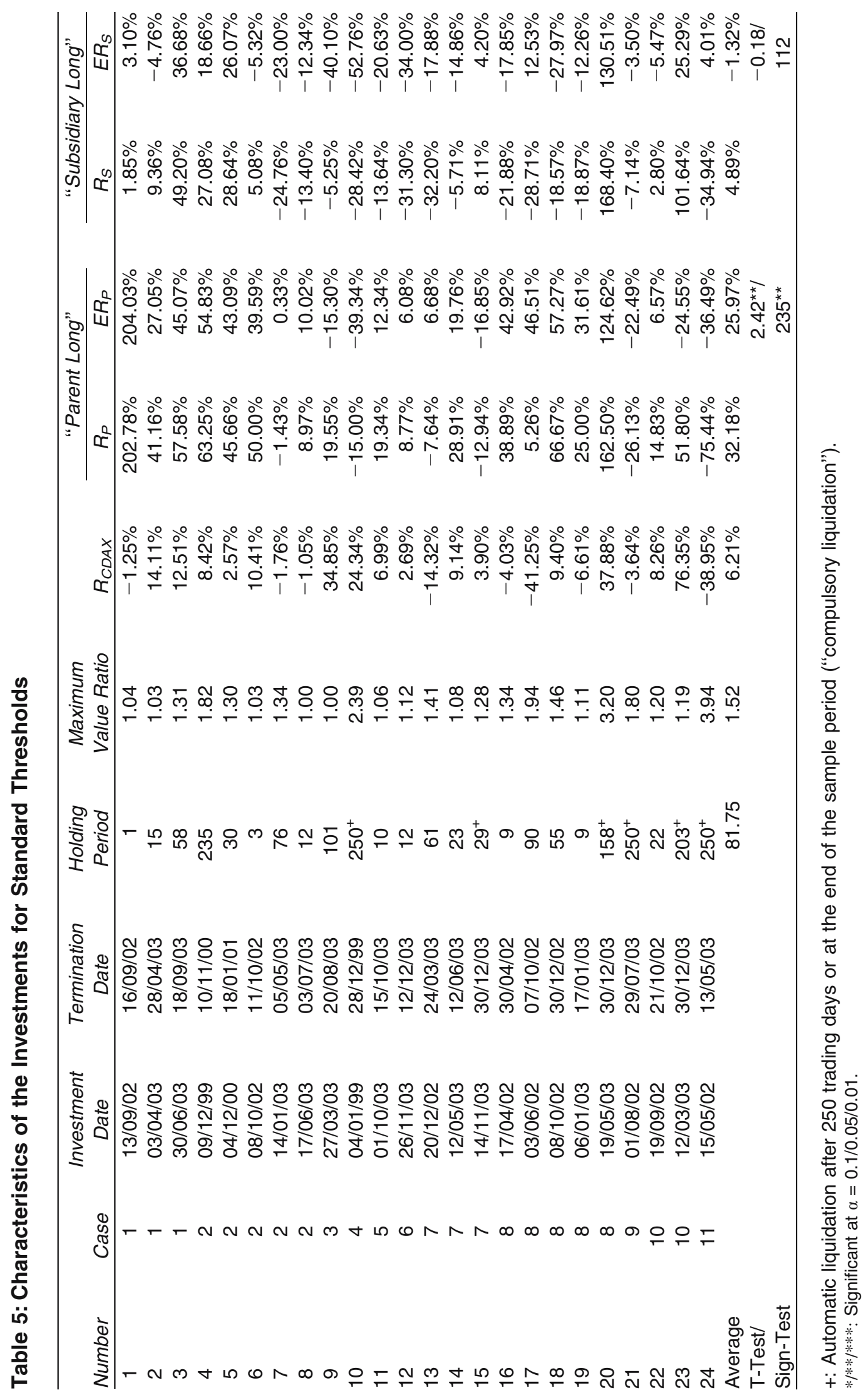


especially at the parent company. However, the high excess return of the parent stocks is accompanied by a high risk. On the one hand, there are cases where the capital employed could be more than doubled (e.g., number 1); on the other hand, very high losses may also occur (e.g., number 24). Apart from the risk that the sell criterion is not reached within the given time interval, the variation of prices during an investment is also an important risk factor. This can be explained by considering the maximum value ratio. After starting an investment, it is subject to strong fluctuations and, on average, rises to a maximum of 1.52. In particular with a long-short strategy, which requires the deposit of collateral because of the short selling, a high value ratio can lead to an additional payment obligation. If the subsidiary's share price does not fall as expected, the collateral might fall below the required maintenance margin. Then the investor would be faced with a margin call and would therefore have to either reduce his position or deposit additional collateral in order to satisfy the maintenance margin requirements. This would reduce the excess returns of the long-short strategy.

In Table 6, the returns of the investments in the standard case are analysed for different market conditions. For this reason, the 24 investments are divided in two sub-groups: one group contains all investments in rising markets, and the other group contains all investments which are carried out in falling markets. Besides the number of investments, the table also shows the average values for the holding period, the maximum value ratio, as well as returns and excess returns.
The results for the standard case seem to be independent of the market condition. When comparing the investments in rising and falling markets, neither the holding period nor the maximum value ratio changes significantly. The excess returns of the "parent (subsidiary) long" investment strategy slightly decrease (increase) with rising markets, whereas with falling markets they slightly increase (decrease). However, altogether the differences are small. Therefore, the influence of market conditions on negative stub value investments is negligible.[20]

In Table 7, the results of the standard thresholds are compared with those of the other buy and sell thresholds. Comparison criteria are the number of investments with the associated convergence ratios (defined as the ratio of regularly terminated investments to all investments), the investment holding period (in trading days) up to the termination of the investment, and the maximum value ratio. Furthermore, the excess return averages for the "parent long" and "subsidiary long" investment strategies are compared. Their significance is examined using the t-test and the sign rank test.

Table 7 shows that with increasing buy threshold the number of investments decreases. While the standard buy threshold 1.00 is reached 24 times, the moderate (cautious) thresholds of 1.25 (1.50) are reached only 16 (6) times. The convergence ratio is constant at first, but then declines with increasing buy threshold. This can be explained by the increasing spread between buy and sell thresholds. Thus, at the moderate threshold with a spread of $0.25,75 \%$ of all investments still converge; at the cautious signals with a spread of 0.50 , only

Table 6: Selected Characteristics for the Investments for Standard Thresholds in Different Market Conditions

\begin{tabular}{|c|c|c|c|c|c|c|c|c|}
\hline \multirow[b]{2}{*}{ Market Condition } & \multirow{2}{*}{$\begin{array}{l}\text { Number of } \\
\text { Investments }\end{array}$} & \multirow{2}{*}{$\begin{array}{l}\text { Holding } \\
\text { Period }\end{array}$} & \multirow{2}{*}{$\begin{array}{c}\text { Maximum } \\
\text { Value Ratio }\end{array}$} & \multirow[b]{2}{*}{$R_{C D A X}$} & \multicolumn{2}{|c|}{ "Parent Long" } & \multicolumn{2}{|c|}{ "Subsidiary Long" } \\
\hline & & & & & $R_{P}$ & $E R_{P}$ & $R_{S}$ & $E R_{S}$ \\
\hline All Positions & 24 & 81.75 & 1.52 & $6.21 \%$ & $32.18 \%$ & $25.97 \%$ & $4.89 \%$ & $-1.32 \%$ \\
\hline Rising Markets & 15 & 80.27 & 1.43 & $17.45 \%$ & $40.14 \%$ & $22.68 \%$ & $19.83 \%$ & $2.37 \%$ \\
\hline Falling Markets & 9 & 83.93 & 1.64 & $-9.54 \%$ & $21.04 \%$ & $30.58 \%$ & $-16.02 \%$ & $-6.48 \%$ \\
\hline
\end{tabular}


Table 7: Comparison of Different Thresholds

\begin{tabular}{llccc}
\hline \multirow{2}{*}{$\begin{array}{c}\text { Buy/Sell Thresholds } \\
\text { Investments (Terminated Regularly) }\end{array}$} & $\begin{array}{c}\text { Standard } \\
\text { (Value Ratio 1.00/0.80) }\end{array}$ & $\begin{array}{c}\text { Moderate } \\
\text { (Value Ratio 1.25/1.00) }\end{array}$ & $\begin{array}{c}\text { Cautious } \\
\text { (Value Ratio 1.50/1.00) }\end{array}$ \\
\multicolumn{2}{c}{ Convergence Ratio } & $24(18)$ & $16(12)$ & $6(3)$ \\
Holding Period & Average & $75.00 \%$ & $75.00 \%$ & $50.00 \%$ \\
Maximum Value Ratio & Standard Deviation & 81.75 & 75.25 & 151.50 \\
& Average & 1.99 & 95.45 & 94.96 \\
"Parent Long" & Standard Deviation & 0.73 & 1.79 & 2.51 \\
& Average ER & $25.97 \%$ & 0.77 & 0.88 \\
"Subsidiary Long" & T-Test/Sign-Test & $2.42^{* *} / 235^{* *}$ & $21.36 \%$ & $39.65 \%$ \\
& Average ER & $-1.32 \%$ & $2.04^{*} / 103^{*}$ & $0.93 / 13$ \\
& T-Test/Sign-Test & $-0.18 / 112$ & $-0.11 \%$ & $-1.31 \%$ \\
\hline
\end{tabular}

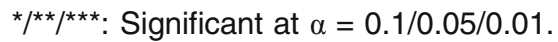

$50 \%$. Initially, the holding period remains constant, but with increasing spread between buy and sell criterion, it also increases. Similarly, the maximum value ratio follows the level of the buy signal and increases from standard to cautious thresholds. Both for the number of trading days and with the maximum value ratio, a very high standard deviation of the individual values can be observed.

Within all buy and sell signals, the "parent long" investment strategy obtains high excess returns of up to $39.65 \%$. The excess returns are statistically significant at the standard and moderate thresholds. Although the highest excess return arises with cautious signals, this is not significant due to the high standard deviation of the excess returns and the small sample size. The "subsidiary long" investment strategy always obtains insignificantly negative excess returns of $-0.11 \%$ (moderate) to $-1.32 \%$ (standard). The results with the moderate and cautious signals confirm the observations with the standard signals: the parent stock always obtains a positive excess return, and the subsidiary stock always a negative excess return. In particular the price of the parent company shares converges because the excess returns of the subsidiary shares are very small compared to those of the parent.

Altogether, statistically significant excess returns can be obtained by negative stub value investments. The parent stocks offer promising invest- ment opportunities. The purchase of the parent stocks is superior to the purchase of the subsidiary stocks. Obviously, in our case, a strategy of buying the parent and shorting the subsidiary (long-short strategy) is unattractive. On the one hand, price adjustments take place especially at the parent, but not at the subsidiary. On the other hand, with a long-short strategy, additional payment obligations must be taken into account. These obligations do not exist for a long-only investment in the parent shares. Therefore, the purchase of the parent stocks is also superior to a long-short strategy.[21]

\section{Explanations for Negative Stub Values}

The results of the previous section support the view that some of the parent/subsidiary pairs were indeed mispriced. In this section, we apply traditional closed-end fund discount and other theories to our sample of negative stub values. First, we want to determine whether the negative stub values which did not converge can be explained by rational theories. Second, we analyse whether the stub values which did converge can also be explained by rational theories.

Explanations for the parent company puzzle can be derived from the closed-end fund discount discussion. In order to explain the divergence between the 
value of a fund and the value of its holdings, MAKIEL (1977) addresses the aspects of taxes, liquidity, and agency costs. LEE/SHLEIFER/ THALER (1991) additionally consider noise trading as an explanation. CORNELL/LIU (2001), SCHILL/ZHOU (2001), and LAMONT/THALER (2003) examine whether these aspects can explain the parent company puzzle. Furthermore, they review off-balance sheet claims as a possible explanation.

Therefore, the following discussion concentrates on five factors: taxes, liquidity, agency costs, noise trading, and off-balance sheet claims. In the following section, it is discussed whether these aspects can explain the results of Section 3.

\subsection{Taxes}

Two different suggestions have been given to explain the role taxes play in the puzzle: the aspects of unrealised capital gains and tax-timing options. As proposed by MAKIEL (1977), unrealised capital gains may be one explanation for the closed-end fund discount. An investor buying into the fund is also buying a capital gain on the securities of the fund which was obtained in the past but as yet is unrealised. This capital gain must be taxed at the time of realisation. Due to additional fiscal charges in relation to a direct investment into the underlying shares, fund prices might trade at a discount to net asset value.

Although the relationship between the closed-end fund and its stakes is comparable with the relationship between the parent and its subsidiary, there are two differences. On the one hand, the stake holding of the parent is usually based on long-term considerations. Thus, the parent firm has (contrary to the closed-end fund) no direct incentive to sell the subsidiary stock so that no taxable capital gain appears. On the other hand, there are mechanisms for avoiding taxation in the case of distribution of the subsidiary shares. Under certain conditions, parent companies from the
USA do not have to pay taxes on the sale of a stake, e.g., if they spin off the shares following the requirements of section 355 of the Federal tax code.[22] That is why unrealised capital gains cannot explain the parent company puzzle.

These arguments are also relevant for the eleven cases in the German capital market. On the one hand, the stakes are mostly long-term, as only a few changes in the participation conditions were observed within the examination period.[23] On the other hand, the institutional settings in Germany also offer the possibility of selling a stake without generating additional fiscal charges for the investors. Since January 2002, according to the corporation tax act (Körperschaftssteuergesetz) Section $8 b$ Paragraph 2, there is a tax exemption for profits made by corporations through the sale of their holdings.[24] Thus, German corporations have no fiscal disadvantages, at least since 2002. Since the law change was already decided upon in 2000 , it might be assumed that the advantages of the new legal situation were already taken into account in the stock prices before 2002. Therefore, this approach also does not explain negative stub values for the German sample.

A further tax-related aspect is discussed by CONSTANTINIDES (1983). Capital gains are subject to taxation only at the time of sale of a stake. Therefore, an investor can minimise the present value of his fiscal charges by timing his sales. However, since investors maintain such an option both with a direct investment (into the underlying securities) and with an indirect investment (into the fund), a price discount must be due to a difference in the volatility of the two investments. Accordingly, in the case of the closed-end fund discount, the volatility of the fund has to be compared with that of its stakes. Since the value of an option increases with the volatility of the underlying share, the fund must exhibit a smaller volatility than its holdings in order to justify a discount.

Consequently, in the case of the parent company puzzle, the volatility of the parent company shares has to be compared with that of the subsidiary 
shares. If the volatility of the parent is less than the volatility of the subsidiary, a smaller value of the tax-timing option could be a reason for the discount. In American studies, the approach of the tax-timing option is generally rejected. At best, a small fraction of the discount can be attributed to such considerations.[25]

In Table 8, the volatilities (defined as the standard deviations of the daily returns) in the sample period for the eleven German parent/subsidiary pairs are compared with each other.

On average, the volatility of the parent $(4.72 \%)$ is $0.57 \%$ higher than the volatility of the subsidiary (4.15\%). Thus, a contrary effect could be justified, i.e., the shares of the subsidiaries should be evaluated at a discount.[26] Even for the cases where the volatility of the subsidiary is higher (cases 2, 4, 5 and 6), the difference is so small that it can hardly justify the negative stub value. Therefore, neither unrealised capital gains nor tax-timing options seem to be meaningful explanations for the puzzle.

\subsection{Liquidity}

Another explanation could be the difference in the liquidity between a direct (into the securities of the fund/in the subsidiary) and an indirect investment (in the fund/in the parent). Thus, in the framework of the block discount hypothesis, the closed-end fund discount reflects the expected price reduction if a large block of shares is sold on the open market within a short period of time.[27] In addition, the liquidity can be limited by legal restrictions, e.g., if shares may not be sold due to contractual agreements. MAKIEL (1977) presents evidence that a part of the closed-end fund discount can be explained by the fact that funds hold non-liquid or contractually blocked shares. The higher the portion of these shares, the higher is the discount.

In American studies on the parent company puzzle, the liquidity argument is rejected. On the one hand, the liquidity of the subsidiaries is small neither in absolute terms nor relative to the parent. On the other hand, no considerable blocked shares were observed.[28]

In this point, the German sample differs from the American samples. First, blocked shares can be identified. In case 1 (Mobilcom and Freenet), the Mobilcom shares of the company founder, Gerhard Schmid, were administered by a trustee from November 2002 to September 2003. Before March 2003 a sale of this block of shares $(42.42 \%$ or 28 million shares) was not possible. In the following

\section{Table 8: Volatility in the Sample Period}

\begin{tabular}{llclc}
\hline Case & \multicolumn{1}{c}{ Parent } & Standard Deviation & \multicolumn{1}{c}{ Subsidiary } & Standard Deviation \\
\hline 1 & Mobilcom & $9.29 \%$ & Freenet & $6.05 \%$ \\
2 & Augusta Technologie & $5.42 \%$ & Pandatel & $6.21 \%$ \\
3 & Fresenius & $2.62 \% *$ & Fresenius Medical Care & $2.54 \%$ \\
4 & Wanderer Werke & $2.02 \%$ & Boewe Systec & $2.23 \%$ \\
5 & USU Software & $2.26 \%$ & USU & $2.70 \%$ \\
6 & Media [Netcom] & $6.45 \%$ & Internolix & $8.49 \%$ \\
7 & TAG Tegernsee & $3.64 \%$ & Bau-Verein zu Hamburg & $2.57 \%$ \\
8 & Essential Wagniskapital & $8.61 \%$ & November & $6.11 \%$ \\
9 & Allianz & $3.31 \%$ & Diverse & $2.43 \%{ }^{* *}$ \\
10 & Münchener Rück & $3.53 \%$ & Diverse & $3.28 \%{ }^{* *}$ \\
11 & WCM & $4.80 \%$ & Diverse & $3.05 \%{ }^{* *}$ \\
Average & & $4.72 \%$ & & $4.15 \%$ \\
\end{tabular}

* : Average of ordinary and preference shares.

**: Average of all stakes. 
Figure 1: Stub Value in Case 1 (Mobilcom and Freenet).

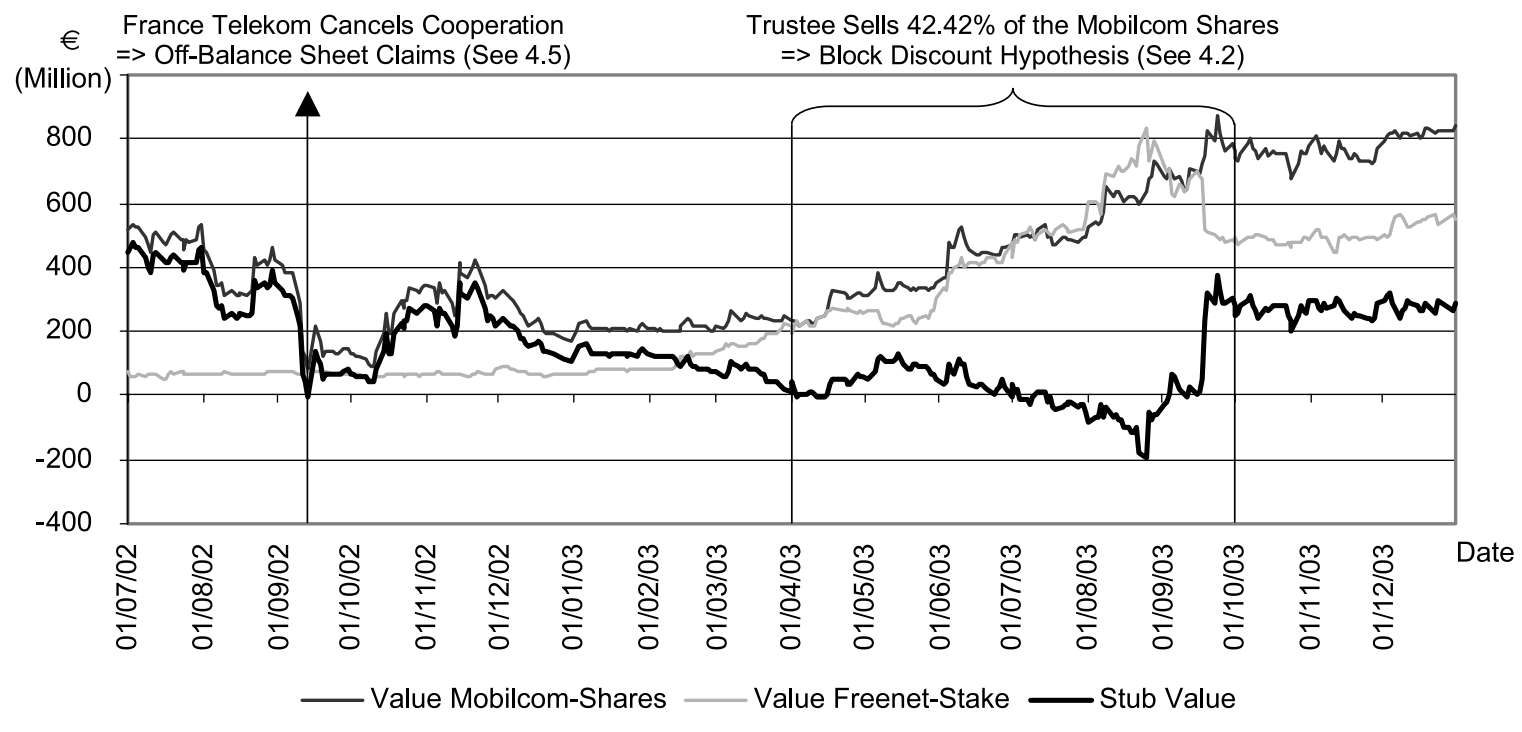

period until September 2003, the entire block was sold at the stock exchange. The effect of these sales is illustrated in Figure 1. The figure shows the value of the Mobilcom shares, the value of the Freenet stake, and the resulting stub value for the period of July 1, 2002 to December 30, 2003.

Although the share prices of both companies increased in a rising market between April 1, 2003, and September 30, 2003, the value of the stake in Freenet first increased disproportionately to the value of the Mobilcom shares. This led to a negative stub value of up to $€ 196.28$ million. The negative stub value might be explained by the block discount hypothesis. In September 2003, the Mobilcom share closed this gap. Probably, the largest portion of the block of shares was already sold at this time. Interestingly, Mobilcom sold $20 \%$ of the Freenet stake on September 18, 2003.

Table 9: Trading Volume (Absolute and Relative) in the Sample Period

\begin{tabular}{|c|c|c|c|c|c|c|}
\hline \multirow[b]{2}{*}{ Case } & \multirow[b]{2}{*}{ Parent } & \multicolumn{2}{|c|}{ Trading Volume } & \multirow[b]{2}{*}{ Subsidiary } & \multicolumn{2}{|c|}{ Trading Volume } \\
\hline & & Absolute & Relative & & Absolute & Relative \\
\hline 1 & Mobilcom & 968,049 & $1.473 \%$ & Freenet & 142,095 & $0.792 \%$ \\
\hline 2 & Augusta & 149,262 & $1.244 \%$ & Pandatel & 95,628 & $1.323 \%$ \\
\hline 3 & Fresenius & $99,040^{*}$ & $0.242 \%$ & Fresenius Medical Care & 566,774 & $0.589 \%$ \\
\hline 4 & Wanderer Werke & 1,215 & $0.047 \%$ & Boewe Systec & 15,811 & $0.262 \%$ \\
\hline 5 & USU Software & 8,948 & $0.052 \%$ & USU & 168 & $0.003 \%$ \\
\hline 6 & Media [Netcom] & 85,787 & $0.339 \%$ & Internolix & 55,039 & $0.405 \%$ \\
\hline 7 & TAG Tegernsee & 10,193 & $0.180 \%$ & Bau-Verein zu Hamburg & 9,315 & $0.110 \%$ \\
\hline 8 & Essential Wagniskapital & 40,171 & $0.210 \%$ & November & 123,196 & $1.649 \%$ \\
\hline 9 & Allianz & $2,186,177$ & $0.570 \%$ & Diverse & $1,631,756^{\star \star}$ & $0.494 \%$ \\
\hline 10 & Münchener Rück & $1,974,350$ & $1.105 \%$ & Diverse & $1,860,876^{\star \star}$ & $0.329 \%$ \\
\hline 11 & WCM & $1,404,383$ & $0.486 \%$ & Diverse & $998,245^{\star \star}$ & $0.537 \%$ \\
\hline Average & & 629,779 & $0.541 \%$ & & 499,900 & $0.590 \%$ \\
\hline
\end{tabular}

*: Sum of ordinary and preference shares.

**: Average of all stakes. 
Obviously, Mobilcom was conscious of the favourable pricing relationship and exploited this opportunity by selling a part of its shares.[29]

Second, we compare the average daily trading volume of the stocks in our sample and identify one case which might be explained by the block discount hypothesis. Table 9 shows the absolute trading volume (i.e., number of shares) and the relative trading volume (i.e., number of shares relative to the issued shares) for both parents and subsidiaries at the Frankfurt stock exchange in the sample period.

On average, the trading volume of the parent companies $(629,779$ shares) exceeds the trading volume of the subsidiaries $(499,900$ shares) by approx. $26 \%$, while the trading volume relative to the issued shares is comparable $(0.541 \%$ versus $0.590 \%$ ). However, this number is mainly driven by three very large values (cases 9, 10, 11).[30] In addition, it should be noted that, in the context of the block discount hypothesis, the relationship of the trading volume of the parent to the subsidiary is not of crucial importance. Rather, the price reduction from the sale of a large block of shares depends on the absolute trading volume. The trading volume is low for only one of the eleven subsidiary companies: in the case of USU (trading volume 168 shares per day or $0.003 \%$ of the issued shares), a sale of a block of shares would definitely have an impact on the share price. Hence, the liquidity argument can explain the puzzle in this case. Thus the liquidity argument appears to be a suitable explanation for cases 1 and 5. At least a part of the negative stub values can be explained by this approach. However, liquidity is unlikely to justify the pricing behaviour of the other cases considered in our study.

\subsection{Agency Costs}

The relationship between owners and managers of a firm represents a typical example of a principalagent relationship. The owners (principals) assign the managers (agents) with the leadership of their company. The agency theory analyses numerous conflicts of interest between the two groups. Following Jensen's free cash flow hypothesis, managers have an incentive to invest free cash flow in unprofitable assets instead of giving it to the owners.[31] Furthermore, managers of diversified companies destroy value for the owners by subsidising inefficient divisions.[32] This opportunistic behaviour leads to additional costs for the owners, called agency costs. Due to agency costs, diversified companies can be worth less than the sum of their individual parts. In the case of the closed-end fund, agency costs are represented by the difference between the benefits and the costs from the management of the fund.[33]

With respect to the parent company puzzle, the agency theory points out that the value of the subsidiary can exceed the value of the parent if the parent invests the cash flow from the subsidiary inefficiently or uses it for the preservation of inefficient divisions. It is therefore crucial whether the parent holds a large and controlling block of shares and controls the cash flow of the subsidiary. If the parent controls the cash flow, their behaviour not only reduces the value of the parent, but also that of the subsidiary. As a result, agency costs cannot be avoided by a direct stake in the subsidiary. Only if the parent does not control the cash flow, can agency costs be an explanation for the puzzle. In American studies, agency costs are rejected since in most cases the parent controls the cash flow. In those instances where the parent does not have control rights, the studies show that the subsidiary generates a negative cash flow.[34] Thus, the subsidiary consumes the cash of the parent, instead of making cash available.

In our sample, most parents control the subsidiary cash flow. In eight cases, the parent possesses the majority of votes.[35] With this majority, they can actively affect the business policy of the subsidiary so that no agency costs can be avoided by a direct stake in the subsidiary. However, in the cases 9 (Allianz) and 10 (Münchener Rück), agency costs can be used to explain the negative stub values. 
Both are large insurance companies which tried to decrease their stake network because of efficiency considerations in the last few years.[36] In these instances, the agency theory is a quite plausible explanation. This also applies to Essential Wagniskapital (case 8), which made numerous unsuccessful investments in the field of the technology industry. However, a general influence of agency costs on all cases should be rejected.

\subsection{Noise Trading}

According to LEE/SHLEIFER/THALER (1991), the closed-end fund discount reflects risk induced by the activity of noise traders. Their analysis is based on the model of DE LONG/SHLEIFER/ SUMMERS/WALDMAN (1990). In this model, market participants are divided into two groups: rationally acting investors and noise traders. The latter base their expectations on noise (e.g., rumours). The analysis of LEE/SHLEIFER/THALER (1991) rests upon three assumptions. First, noise traders hold and trade more shares of the fund than shares of the underlying. Second, noise trader actions change randomly over time but are correlated across different securities. Third, there exist impediments to arbitrage which prevent rationally acting arbitrageurs from eliminating the mispricing. Under these conditions, they show that an investor in a closed-end fund-apart from the risk of the underlying shares - also bears a high noise trader risk. Thus, the investment into the closed-end fund is riskier than the direct investment. Therefore, the fund must be traded at a discount to its net asset value.

In American studies on the parent company puzzle, a certain explanation value is attached to the noise trader approach. CORNELL/LIU (2001), p. 360 , consider a combination of the noise trader demand and impediments to short selling as the best explanation for the puzzle. On the one hand, the free float of the subsidiary is small compared to the parent in their sample. On the other hand, they find high costs associated with security lending. As long as the demand for shares of the subsidiary is large, the free float is small, and arbitrage costs prevent the elimination of a mispricing, an anomaly can occur and remain for a longer time. High demand and short sale restrictions lead to large price fluctuations and thus to negative stub value situations.

Table 10 lists the free float of the shares in our sample on December 30, 2002. The data are taken

\section{Table 10: Free Float}

\begin{tabular}{|c|c|c|c|c|}
\hline Case & Parent & Free Float & Subsidiary & Free Float \\
\hline$\overline{1}$ & Mobilcom & $29.30 \%$ & Freenet & $27.11 \%$ \\
\hline 2 & Augusta Technologie & $93.00 \%$ & Pandatel & $35.50 \%$ \\
\hline 3 & Fresenius & $14.56 \%$ * & Fresenius Medical Care & $49.20 \%$ \\
\hline 4 & Wanderer Werke & $42.88 \%$ & Boewe Systec & $40.62 \%$ \\
\hline 5 & USU Software & $74.10 \%$ & USU & $4.01 \%$ \\
\hline 6 & Media [Netcom] & $40.90 \%$ & Internolix & $4.90 \%$ \\
\hline 7 & TAG Tegernsee & $80.00 \%$ & Bau-Verein zu Hamburg & $12.08 \%$ \\
\hline 8 & Essential Wagniskapital & $49.90 \%$ & November & $82.06 \%$ \\
\hline 9 & Allianz & $71.00 \%$ & Diverse & $28.16 \%$ ** \\
\hline 10 & Münchener Rück & $74.30 \%$ & Diverse & $35.85 \%$ ** \\
\hline 11 & WCM & $55.06 \%$ & Diverse & $24.80 \%{ }^{* *}$ \\
\hline Average & & $56.82 \%$ & & $31.30 \%$ \\
\hline
\end{tabular}

*: Average of ordinary and preference shares.

**: Average of all stakes. 
from the business reports and from the investor relations information of the corporations involved. Along the lines of CORNELL/LIU (2001), the free float of the subsidiaries $(31.30 \%)$ is, on average, smaller than the free float of the parents (56.82\%).[37] For example, in the case of USU (case 5), only $4.01 \%$ of the shares are in free float. This also corresponds to a small trading volume of 168 shares per day. But there are also subsidiaries with a very high free float in the sample. For example, $49.20 \%$ of the shares of Fresenius Medical Care (case 3) are available as free float. With a trading volume of over 500,000 shares per day, the subsidiary of Fresenius is one of the most liquid shares in the sample.

There is little information available concerning the possibilities and costs of security lending in Germany. In contrast to the American capital market, where the security lending business has already existed for several decades, security lending in Germany is quite new. Only since 1990 has the German Cash Association (Deutscher Kassenverein) offered the possibility of lending securities for a fee.[38] In the meantime, the market for security lending in Germany has developed further. The size of the market is estimated to be approximately $€ 150$ billion per year.[39] The lending business is arranged by an internationally standardised basic agreement for security lending.[40] However, there are only few institutions which offer the execution and completion of security lending.[41] Rather, central securities depositories, security collecting banks, and clearing houses might be chosen as counter party for a borrower.[42] The costs of security lending are based individually on the market condition and the negotiating position of the contract parties.

In principle, short selling of the shares in the sample seems possible. However, it is especially questionable in the case of less liquid shares whether a sufficient number of shares can be lent at appropriate costs. For that reason, it might barely be possible to sell short shares of USU, while this is certainly possible with shares of
Fresenius Medical Care. Therefore, in individual cases, it is conceivable that a change of the pricing relationship is prevented due to the impediments to short selling or due to high costs of security lending. However, a detailed analysis is not possible due to a lack of data concerning the possibilities and the costs of security lending. In general, the approach of noise trading appears to be a suitable explanation for the puzzle in individual instances, but a conclusive statement is not yet possible.

\subsection{Off-Balance Sheet Claims}

SCHILL/ZHOU (2001) look at two problem areas which explain the parent company puzzle using off-balance sheet claims. First, a subsidiary is protected against potential legal liabilities of the parent. Second, the equity of the parent might be diluted by derivative financial instruments, such as stock options for staff members or convertible bonds. Then the calculated market capitalisation does not correspond to the real market capitalisation.

If investors anticipate large potential liabilities for the parent but expect that the subsidiary is shielded from any such claims, then the parent might trade at a discount in comparison to the subsidiary. In our case, this approach provides a suitable explanation for the negative stub values of three companies in financial or operational distress. Mobilcom (case 1) could barely avoid insolvency in September 2002 after France Telecom cancelled an important cooperation contract. The collapse was only averted with the support of the Federal Government of Germany.[43] Essential Wagniskapital (case 8) first had to accept high losses due to unsuccessful investments in the technology industry during 2001 and 2002. Then bad information politics and inquiries about the managing director led to a lack of confidence by most shareholders.[44] Today, WCM (case 11) still suffers from an analyst study done in June 
Table 11: Issued and Potential Shares

\begin{tabular}{llcclcc}
\hline & & $\begin{array}{c}\text { Issued } \\
\text { Shares } \\
\text { (in Million) }\end{array}$ & $\begin{array}{c}\text { Potential } \\
\text { Shares } \\
\text { (in Million) }\end{array}$ & \multicolumn{1}{c}{ Subsidiary } & $\begin{array}{c}\text { Issued } \\
\text { Shares } \\
\text { (in Million) }\end{array}$ & $\begin{array}{c}\text { Potential } \\
\text { Shares } \\
\text { (in Million) }\end{array}$ \\
\hline 1 & Mobilcom & 65.70 & 0.50 & Freenet & 17.95 & 0.49 \\
2 & Augusta & 12.00 & 1.94 & Pandatel & 7.23 & 0.04 \\
3 & Fresenius & $40.97^{\star}$ & $1.24^{\star}$ & Fresenius Medical Care & 96.19 & 2.09 \\
4 & Wanderer Werke & 2.60 & 0.00 & Boewe Systec & 6.04 & 0.06 \\
5 & USU Software & 17.21 & 0.00 & USU & 5.74 & 0.34 \\
6 & Media [Netcom] & 25.34 & 0.39 & Internolix & 13.59 & 0.00 \\
7 & TAG Tegernsee & 5.66 & 0.00 & Bau-Verein zu Hamburg & 8.45 & 0.50 \\
8 & Essential Wagniskapital & 19.10 & 0.11 & November & 7.47 & 0.12 \\
9 & Allianz & 383.75 & 0.14 & Diverse & $330.34^{\star *}$ & $2.38^{\star *}$ \\
10 & Münchener Rück & 178.67 & 0.00 & Diverse & $566.03^{* *}$ & $15.14^{* *}$ \\
11 & WCM & 288.83 & 1.33 & Diverse & $186.06^{* *}$ & $0.19^{* *}$ \\
\hline
\end{tabular}

* : Sum of ordinary and preference shares.

**: Average of all stakes.

2002 which reported alleged falsification of the balances and the subsequent credit shortage.[45] In all three examples, the bad news caused a slump in the stock prices of the parent, while the shares of the subsidiary were not affected. This might have led to the negative stub values.

Off-balance derivative financial instruments, such as stock options or convertible bonds, can bias the equity market value. To investigate the importance of derivative financial instruments, the market value of all outstanding contingent claims on securities has to be estimated. For the available sample, all data on stock options and convertible bonds on December 30, 2002, were collected from the business reports of the companies involved. Table 11 contrasts the issued and the potential shares for all companies in our sample.

We only find one company where the potential shares reach a considerable level compared with the number of issued shares. At Augusta, two million potential shares face twelve million issued shares. However, both stock options and conversion price are far out of the money, so that an execution of the claims and an increase in capital are improbable. Thus, despite the issue of convertible bonds, Augusta does not report dilution in the earnings per share in its business report because the stock price (December 30, 2003: €2.80) is far below the conversion price $(€ 42.30)$. For that reason, there is no considerable dilution of the determined market values. The impact of derivative financial instruments is not sufficient to explain the observed value ratios.

\section{Summary}

In this paper, we investigated the German stock market between January 4, 1999, and December 30,2003 , with regard to negative stub values or parent company puzzles. These are situations where a firm's market value is less than the value of its ownership stake in a publicly traded subsidiary. According to MITCHELL/PULVINO/ STAFFORD (2002), negative stub values indicate clear arbitrage opportunities, which sometimes exist and persist. The authors find that uncertainty about both the characteristics of negative stub value investments and the risks of these investment strategies limit arbitrage. In 16 years of data, MITCHELL/PULVINO/STAFFORD were able to find 82 examples of negative stub values. In five years, we were able to find 11 opportunities while 
restricting the analysis to the German stock market. Taking into account the length of the time periods and the size of the American versus the German stock market, the numbers of negative stub values seem to be comparable. Furthermore, MITCHELL/PULVINO/STAFFORD (2002) find that $30 \%$ of the time the negative stub value investments terminate without convergence of the prices. In our sample, about $25 \%$ of the cases terminate before the mispricings are eliminated. Again, these numbers seem to be comparable.

In contrast to our study, MITCHELL/PULVINO/ STAFFORD (2002) find that the investment strategy "parent long" produces no abnormal returns, while the strategy "subsidiary long" produces a reliably negative return. From these results, the authors conclude that the subsidiary shares are overpriced before market forces push them back to fundamentals. In our study, we find quite the opposite. On average, the "parent long" investment strategy produces a return of more than $20 \%$ in excess of the return of a market index and the "subsidiary long" investment strategy produces an insignificantly negative excess return of $1.32 \%$. Of course, our results need to be judged carefully due to the small sample size. But the results suggest that that the parent company share somehow became underpriced before market forces pushed them back to fundamentals. This finding supports the view that uncertainty and the costs associated with imperfect information appear to be the biggest friction impeding arbitrage.[46]

In order to complement our analysis, we applied different traditional closed-end fund discount and other theories to our sample of negative stub values. Different explanations such as taxes, liquidity, agency costs, noise trading, and offbalance sheet claims were presented and discussed under consideration of the institutional settings in Germany. We found that two of the three negative stub values (case 9 and 11) in which the prices did not converge as desired could be explained by agency costs and off-balance sheet claims. We found no explanation for the negative stub value in case 4. Of the investments which did converge, one half (case 1, 5, 8, and 10) could be explained by rational theories, while the other half (case 2, 3, 6, and 7) could not be explained.[47]

To conclude, this study supports the view of MITCHELL/PULVINO/STAFFORD (2002), that mispricings exist and persist because of costs associated with imperfect information. Due to imperfect information, the ex ante expected profits of finding and exploiting negative stub values may be so small that arbitrageurs do not enter the business of eliminating mispricings. 


\section{ENDNOTES}

[1] See, e.g., the buy recommendations of "ExtraChancen" (11/07/03), "Wertpapier" (17/07/03), or "Prior Börse" (08/08/03) on the investor relations site of Mobilcom http://www.mobilcom.de).

[2] See MITCHELL/PULVINO/STAFFORD (2002), p. 552.

[3] See CORNELL/LIU (2001), p. 341.

[4] Throughout the paper, we refer to a parent and a subsidiary independent of the concrete extent of the stake.

[5] The parent company puzzle is related to the closed-end fund discount. The latter considers the differences in market and net asset values of closed-end funds. Although their holdings in publicly traded stocks are the only assets of closed-end funds, the funds are regularly traded at a discount to the market value of their holdings.

[6] SCHILL/ZHOU (2001) examine Internet subsidiary carve-outs and find that in four of the twelve cases the value of the parent's holdings exceeds the total value of the parent company. They conclude that the traditional closed-end fund discount theories do not fully explain the parent-to-subsidiary value relationship in Internet carve-outs. LAMONT/THALER (2003) study a sample of equity carve-outs in US technology stocks and come to the conclusion that arbitrage does not eliminate the mispricings because of short-sale constraints.

[7] See MITCHELL/PULVINO/STAFFORD (2002), p. 554.

[8] Only those parent/subsidiary pairs are included in the sample in which the parent is a German company. Of course, cases can be found in which the enterprises involved are foreign companies listed on the German stock market (e.g., France Telekom and Orange). Moreover, in some instances very small stakes were not considered for practical reasons. For example, Allianz has many other stakes. In these cases, the determined stub value represents an upper limit. The real stub value is even lower.
[9] The 18 subsidiaries are: AGF-Assurances Generales de France S.A., Allianz Lebensversicherungs AG, BASF AG, Beiersdorf AG, BMW Group AG, Deutsche Börse AG, Deutsche Lufthansa AG, E.ON AG, Eurohypo AG, Heidelbergcement $A G$, KarstadtQuelle $A G$, Linde AG, MAN AG, Münchener Rück AG, RAS Riunione Adriatica di Sicurta S.P.A., RWE AG, Schering AG, and Siemens AG.

[10] The 6 subsidiaries are: Allianz AG, Bayerische Hypo- und Vereinsbank AG, Commerzbank AG, Ergo Versicherungsgruppe AG, Fortis N.V., and RWE AG.

[11] The 4 subsidiaries are: Commerzbank AG, IVG Holding AG, Klöckner-Werke AG, and RSE Grundbesitz- und Beteiligungs AG.

[12] CORNELL/LIU (2001), SCHILL/ZHOU (2001) as well as LAMONT/THALER (2003) almost exclusively consider companies in the technology industry, whereas MITCHELL/PULVINO/ STAFFORD (2002) examine companies from the Old and New Economies as well.

[13] In the USA, there are, e.g., spin-off funds which denote investments in negative stub values as an important component of their strategy. For example, see http://www.spinoffadvisors.com.

[14] For the definition of buy and sell signals, it makes sense to define a certain interval for entry and exit, instead of giving a fixed value ratio. Thus, the threshold values are based on a clear adjustment of market prices instead of marginal changes. See MITCHELL/PULVINO/ STAFFORD (2002), p. 558.

[15] We use the moderate and cautious thresholds in order to determine the sensitivity of our calculations to the buy and sell signals chosen. We refer to these thresholds as "moderate" and "cautious" because increasing the buy threshold gives the investors some cushion over their mispricing estimates.

[16] This approach is called market adjusted return model. Beyond that, the excess returns were also computed with the mean adjusted return model and the market model. The results are 
almost identical. For a similar approach see, e.g., BROMANN/SCHIERECK/WEBER (1997), p. 606.

[17] Transaction costs may be neglected here as there are only two (building and termination of the position) transactions per investment necessary. The resulting costs might reduce the calculated excess returns at most by some tenth of a percent.

[18] The tests examine whether the average excess return differs significantly from zero (bilateral test). See HARTUNG (2002), p. 179 and pp. 243-247 for further details.

[19] In calculating the average, a problematic aggregation occurs over time periods of varying length. This problem can be solved by the determination of "annualised" returns. However, on the assumption of investing at the interest rate of $0 \%$ for the rest of the year after the termination of an investment, the average values calculated correspond to annualised values. Therefore, they represent a good approximation.

[20] The excess returns in rising and falling markets were compared using the Wilcoxon rank-sum test. See HARTUNG (2002), pp. 513-520. No significant test values were observed.

[21] These observations only correspond partially to the results of MITCHELL/PULVINO/STAFFORD (2002). They question the benefit of a long-short strategy, especially with respect to additional payment obligations and costs of short selling. However, in contrast to our results, they do not find abnormally positive returns at the parent and abnormally negative returns at the subsidiary. See MITCHELL/ PULVINO/STAFFORD (2002), pp. 582-583.

[22] See CORNELL/LIU (2001), p. 345.

[23] Apart from the cases with many subsidiaries (cases 9 to 11), only 4 noteworthy changes were observed within the examination period: Mobilcom (case 1) reduced its stake from $73 \%$ to $53 \%$ on 18/09/03. Media [Netcom] (case 6) increased its stake from $30 \%$ to $60 \%$ on $01 / 08 / 02$ and again to $95 \%$ on $10 / 09 / 02$. TAG Tegernsee (case 7 ) increased its stake from $44 \%$ to $88 \%$ on 25/01/02.

[24] See SCHEFFLER (2003), p. 680.

[25] See SCHILL/ZHOU (2001), p. 14.

[26] This statement applies only tendential because, according to the Wilcoxon rank-sum test, the difference in the volatility is insignificant.

[27] See SCHILL/ZHOU (2001), p. 17.

[28] See CORNELL/LIU (2001), pp. 345-346.

[29] CORNELL/LIU (2001) similarly observe some company transactions which take advantage of a negative stub value. See CORNELL/LIU (2001), pp. 361-364.

[30] The Wilcoxon rank-sum test on the difference in the trading volume of parent and subsidiary delivers only insignificant results.

[31] See JENSEN (1986).

[32] See SHIN/STULZ (1998).

[33] See CORNELL/LIU (2001), p. 343.

[34] See SCHILL/ZHOU (2001), p. 18.

[35] Also see Table 1.

[36] See, e.g., HEGMANN (2003).

[37] The Wilcoxon rank-sum test on the difference in the free float of parent and subsidiary is significant at $\alpha=0.01$.

[38] See BLITZ/ILLHARDT (1990), p. 142.

[39] See INTERNATIONAL ORGANIZATION OF SECURITIES COMMISSIONS/BANK FOR INTERNATIONAL SETTLEMENTS (1999), p. 82.

[40] See BERNER (1999), p. 867.

[41] Only the financial services companies Euroclear, CEDEL, and the German Cash Association offer institutionalised settlement systems. However, these three only have a small share of the security lending market. See EDELMANN/ ELLER (1996), pp. 32-34.

[42] See HEINRICH (1999), p. 1396.

[43] Also see FEDERAL GOVERNMENT OF GERMANY (2002) and Figure 1.

[44] See, e.g., VOGEL (2002).

[45] See KRAMER (2002).

[46] See MITCHELL/PULVINO/STAFFORD (2002), p. 582 . 
[47] Within this conclusion we exclude the three investments that were not terminated before 30/ $12 / 03$. However, two of these investments (number 15 and 23) converged within 2004, while investment number 20 did not.

\section{REFERENCES}

BERNER, M. (1999): "Der neue Rahmenvertrag für Wertpapierdarlehen", Die Bank, pp. 867-871.

BLITZ, J. and J. ILLHARDT (1990): "Wertpapierleihe beim Deutschen Kassenverein", Die Bank, pp. 142-145.

BROMANN, O., D. SCHIERECK and M. WEBER (1997): "Reichtum durch (anti-)zyklische Handelsstrategien am deutschen Aktienmarkt", Zeitschrift für betriebswirtschaftliche Forschung, pp. 603-616.

CONSTANTINIDES, G. (1983): “Capital Market Equilibrium with Personal Tax", Econometrica, pp. 611-636.

CORNELL, B. and Q. LIU (2001): "The Parent Company Puzzle: When is the Whole Worth Less Than One of its Parts?", Journal of Corporate Finance, pp. 341-366.

DE LONG, J. B., A. SHLEIFER, L. H. SUMMERS and R. J. WALDMANN (1990): "Noise Trader Risk in Financial Markets", Journal of Political Economy, pp. 703-738.

EDELMANN, E. and R. ELLER (1996): Wertpapierdarlehen und Wertpapierpensionsgeschäfte, Bonn: Economica Verlag.

FEDERAL GOVERNMENT OF GERMANY (2002): "Bundesregierung wendet Insolvenz von MobilCom ab", 19/09/02, http://www.bundesregierung.de.

HARTUNG, J. (2002): Statistik, 13th ed., München, Wien: Oldenburg.

HEGMANN, G. (2003): "Paul Achleitner: Entflechter der Deutschland AG", Financial Times Deutschland, online edition, 24/10/03, http://www.ftd.de.

HEINRICH, G. C. (1999): "Zunehmendes Interesse für die Wertpapierleihe", Zeitschrift für das gesamte Kreditwesen, pp. 1396-1398.

INTERNATIONAL ORGANIZATION OF SECURITIES COMMISSIONS and BANK FOR INTERNATIONAL SETTLEMENTS (1999): Securities Lending Transactions: Market Development and Implications, Report prepared by the Technical Committee of the International Organization of Securities Commissions and the Committee on Payment and Settlement Systems, Basel. 
JENSEN, M. C. (1986): "Agency Costs of Free Cash Flow, Corporate Finance and Takeovers", American Economic Review, pp. 323-329.

KRAMER, T. (2002): "Analyse löst Kursabsturz bei WCM aus", Financial Times Deutschland, online edition, 18/06/02, http://www.ftd.de.

LAMONT, O. A. and R. H. THALER (2003): "Can the Market Add and Subtract? Mispricing in Tech Stock Carve-outs", Journal of Political Economy, pp. 227268.

LEE, C. M. C., A. SHLEIFER and R. H. THALER (1991): "Investor Sentiment and the Closed-End Fund Puzzle", Journal of Finance, pp. 75-110.

MAKIEL, B. G. (1977): "The Valuation of Closed-End Investment Company Shares", Journal of Finance, pp. 847-859.

MITCHELL, M., T. PULVINO and E. STAFFORD (2002): "Limited Arbitrage in Equity Markets", Journal of Finance, pp. 551-584.

SCHEFFLER, W. (2003): "Beteiligungsveräußerungen durch Kapitalgesellschaften: Die Steuerbefreiung nach $\S 8 \mathrm{~b}$ Abs. $2 \mathrm{KStG}$ ist gerechtfertigt", Der Betrieb, pp. 680-685.

SCHILL, M. J. and C. ZHOU (2001): "Pricing an Emerging Industry: Evidence from Internet Subsidiary CarveOuts", Financial Management, Autumn, pp. 5-33.

SHIN, H. and R. M. STULZ (1998): "Are Internal Capital Markets Efficient?", Quarterly Journal of Economics, pp. 531-552.
VOGEL, H. (2002): "Glasauer Wagniskapital sieht Überleben dank Liquidität gesichert", VWDMeldung, 28/02/02, http://www.finanztreff.de.

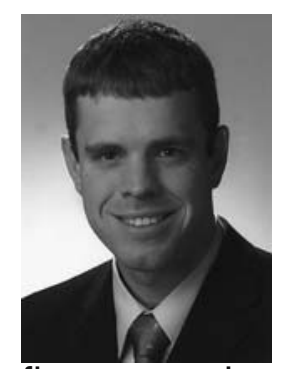

MARTIN ELING is currently a doctoral student and is working at the Institute of Insurance Economics at the University of St. Gallen, Switzerland. He studied business administration with a focus on finance and operations research in Muenster (Germany), where he graduated in 2003. His main research interests are empirical finance, performance measurement, and hedge funds.

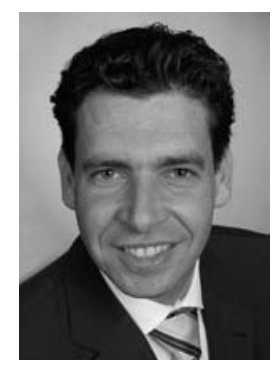

FRANK SCHUHMACHER is a Professor of Business Administration at the University of Leipzig (Germany). His main research interests are in the areas of asset management and corporate finance. 